\title{
State Public Policies and the Racial/Ethnic Stratification of College Access and Choice in the State of Maryland
}

\author{
Laura W. Perna \\ University of Pennsylvania, Iperna@gse.upenn.edu \\ Patricia Steele \\ Susan Woda \\ Taifa Hibbert
}

Follow this and additional works at: https://repository.upenn.edu/gse_pubs

Part of the Higher Education Commons, and the Social and Cultural Anthropology Commons

\section{Recommended Citation}

Perna, L. W., Steele, P., Woda, S., \& Hibbert, T. (2004). State Public Policies and the Racial/Ethnic Stratification of College Access and Choice in the State of Maryland. The Review of Higher Education, 28 (2), 245-272. http://dx.doi.org/10.1353/rhe.2004.0037

This paper is posted at ScholarlyCommons. https://repository.upenn.edu/gse_pubs/372

For more information, please contact repository@pobox.upenn.edu. 


\title{
State Public Policies and the Racial/Ethnic Stratification of College Access and Choice in the State of Maryland
}

\author{
Abstract \\ This study uses descriptive analyses of data from multiple sources to examine changes during the 1990s \\ in the racial/ethnic stratification of college access and choice in Maryland and to explore state public \\ policies that may have influenced changes in the demand for and supply of higher education for students \\ of different racial/ethnic groups during this period. We also discuss the potential implications of recent \\ state policies on future enrollment stratification in the state. \\ Disciplines \\ Education | Higher Education | Social and Cultural Anthropology
}


The Review of Higher Education

Winter 2005, Volume 28, No. 2, pp. 245-272

Copyright (C) 2004 Association for the Study of Higher Education

All Rights Reserved (ISSN 0162-5748)

\title{
State Public Policies and the Racial/Ethnic Stratification of College Access and Choice in the State of Maryland
}

\author{
Laura W. Perna, Patricia Steele, Susan Woda, \\ and Taifa Hibbert
}

Although educational attainment has generally increased over the past 30 years, on average, Blacks and Hispanics continue to attain lower levels of education than Whites (National Center for Education Statistics [NCES], 2003a). Racial/ethnic group differences in college enrollment are one source of differences in educational attainment, as smaller shares of Blacks and Hispanics than of Whites enroll in college. About half of Blacks (55\%) and Hispanics (53\%) who completed high school in 2001 enrolled in college in the fall after completing high school, compared with two-thirds (64\%) of Whites (NCES, 2003b). The representation of Blacks and Hispanics among college enrollments varies across the 50 United States, ranging in fall 2000 from less than $1 \%$ in Idaho, Montana, South Dakota, Utah, and Wyoming to more than one-third in Mississippi for Blacks, and from less than $1 \%$ in

LAURA W. PERNA is Assistant Professor of Higher Education, University of Maryland, College Park, where PATRICIA STEELE and SUSAN WODA are doctoral candidates, and TAIFA HIBBERT is a master's degree recipient. Address queries to Laura W. Perna, EDPL, College of Education, University of Maryland, 2111 Benjamin Building, College Park, MD 20742; telephone: (301) 405-2220; email: lperna@umd.edu. 
Mississippi, North Dakota, South Dakota, and West Virginia to 40\% in New Mexico for Hispanics (NCES, 2003a).

State differences in college enrollment by race/ethnicity reflect, at least in part, differences in the racial/ethnic composition of a state's college-eligible population (e.g., high school graduates). Nonetheless, although they do not examine racial/ethnic group differences in college enrollment across states per se, several recent reports imply that variations in state public policies may also be a source of state variations in college enrollment patterns (e.g., Kipp, Price, \& Wohlford, 2002; National Center for Public Policy and Higher Education, 2002). Research shows variations across states in policies that may be related to college enrollment, including criteria for awarding student financial aid (Institute for Higher Education Policy, 2002), types and amounts of state financial aid awarded (Zumeta, 1992), and state appropriations to private higher education institutions (Zumeta, 1992).

Some research (Kane, 1999; Perna \& Titus, 2004) supports the assumption that state public policies are related to college enrollment patterns. Statelevel analyses show that an increase in tuition at public four-year institutions is associated with an increase in enrollment at public two-year institutions but a decrease in enrollment at public four-year institutions (Kane, 1995). Multilevel analyses indicate that, even after controlling for student-level characteristics, public policies related to appropriations, tuition, financial aid, and $\mathrm{K}-12$ academic preparation contribute to differences across states both in whether students go to college and in the type of institution students attend (Perna \& Titus, 2004).

Yet such research describes the relationship between state public policies and college enrollment "on average," necessarily simplifying the complexities of state policies and their effects on enrollment. In addition, little is known about the ways in which state public policies contribute to racial/ ethnic group differences in college enrollment patterns within a state. This study addresses this knowledge gap by exploring the relationship between state public policies and college enrollment in one state, the state of Maryland. The study uses descriptive analyses of data from multiple sources to examine changes in the racial/ethnic stratification of college enrollment in terms of both access and choice during the 1990s and to identify state public policies that may have influenced the demand for and supply of higher education for students of different racial/ethnic groups. The data show that the racial/ethnic stratification of college access and choice increased in Maryland during the 1990s even with state policies designed to increase the demand for and supply of higher education. Moreover, our review of policies established during the late 1990s and early 2000s suggests that racial/ ethnic stratification will increase in the coming decade. 


\section{State Government Intervention in the Higher Education Market}

The conceptual framework for this study relies on economic theories about the public sector (Paulsen, 2001a). Economists (e.g., Kane, 1999; Paulsen, 2001a) argue that government intervention in the higher education market is warranted for at least four reasons. First, individual participants do not capture all of the benefits that higher education produces; the benefits "spill over" to nonparticipants. Because enrollment decisions are based on an assessment of individual benefits without consideration of the benefits that accrue to society, the level of investment in higher education that would occur without market intervention is less than optimal (Paulsen, 2001a; Steuerle, 2001). Government policies address the tendency to underinvest in higher education by reducing the costs to individual participants via direct appropriations to institutions and financial aid to students (Hansen \& Weisbrod, 1969).

Government intervention may also correct for a second market failure: the inability of participants to use their post higher education level of human capital as collateral against which to borrow funds needed to pay educational costs (Kane, 1999; Paulsen, 2001a). In the absence of market intervention, private capital markets fail to provide funds to students, again resulting in an underinvestment in higher education. Government policies address this limitation by providing incentives for lenders to make funds available for students to borrow and allocating funds to students in the form of grants.

A third justification for government intervention is that individuals not only lack perfect information about college opportunities but also have differential access to such information (Kane, 1999). Unlike clients of for-profit firms in competitive industries, buyers of higher education are unable to obtain complete information about the "product" until they "experience" it (Winston, 1999). Potential first-generation college students, a large percentage of whom are Black and Hispanic (NCES, 2001), are likely to be particularly disadvantaged by this characteristic of higher education markets since they cannot rely on their parents for relevant information. Policies may address this market failure by disseminating information about college and financial aid programs as well as by supporting initiatives that increase students' college-related knowledge.

Government intervention in the higher education market is also warranted when the public supports a reduction in inequities across groups (Paulsen, 2001a). Michael Paulsen argues that state policies that increase higher education enrollment are a more efficient method of equalizing incomes than other government interventions including direct transfers to low-income individuals or individuals from underrepresented racial/eth- 
nic groups. By building human capital, a policy that promotes college enrollment enables individuals to earn higher incomes throughout their lifetimes, thereby eliminating the need for the public sector to provide annual income subsidies to these individuals.

State government interventions in the market may stimulate the supply of and/or demand for higher education (Paulsen, 2001a, 2001b). Supplyside interventions include state appropriations to colleges and universities; such appropriations reduce the cost to higher education institutions of providing the education and allow institutions to reduce the sticker price of the education charged to students (Paulsen, 2001b). Demand-side interventions increase the number of students who enroll in higher education by reducing the net price that students pay for higher education (e.g., financial aid to students), encouraging families to save for college (e.g., 529 college savings plans), improving the college-readiness and academic preparedness of students (e.g., K-12 education reforms), and reducing structural barriers to college entry (e.g., desegregation initiatives) (Paulsen, 2001b). Changes in demographics and economic conditions may also affect the demand for higher education (Sireci, Zanetti, \& Berger, 2003).

\section{Research Methods}

This study examines changes during the 1990s in the racial/ethnic stratification of college access and choice in Maryland and explores state public policies that may have influenced changes in the demand for and supply of higher education for students of different racial/ethnic groups during this period. The study addresses the following research questions:

1. In what types of colleges and universities do individuals of different racial/ethnic groups in Maryland enroll? How has the racial/ethnic stratification of college access and choice changed during the 1990s?

2. What state public policies may have influenced the demand for and supply of college enrollment at different types of institutions in Maryland during the 1990s?

To address the research questions, the study relies on descriptive analyses of data from a variety of sources, including published and unpublished reports from the Maryland Higher Education Commission (MHEC), Maryland State Department of Education (MSDE), University System of Maryland (USM), and the Maryland General Assembly. The study also involves analyses of data from the Integrated Postsecondary Education Data System (IPEDS) Fall Enrollment surveys and the Common Core of Data, annual surveys that are sponsored by the U.S. Department of Education.

The enrollment analyses describe patterns and trends over time at different types of institutions. Because bachelor's degree completion rates are higher for students who enroll full-time rather than part-time (Cabrera, 
LaNasa, \& Burkham, 2001), we focus on the enrollment of first-time, fulltime freshmen.

This study excludes some institutions that are located in the state. We exclude the U.S. Naval Academy (the federal, not state, government supports this institution), the University of Baltimore (it does not enroll freshmen or sophomores), the University of Maryland, Baltimore (it offers only post-baccalaureate educational programs), and the University of Maryland Biotechnology Institute and University of Maryland Center for Environmental Science (they do not award degrees). We also exclude private colleges and universities that do not receive unrestricted direct state appropriations. Baltimore International College, one of the 14 private institutions that receives state aid, is also excluded because it did not consistently report enrollment data to IPEDS. These exclusions likely have minimal impact on the analyses, as these institutions enrolled less than $2 \%$ of the state's first-time, full-time freshmen at public and private nonprofit fouryear colleges and universities in fall 1997.

\section{LiMiTATIONS}

This study is subject to several limitations. First, the examination of enrollment trends does not account for migration. Because IPEDS does not collect data on the race/ethnicity of students who migrate, implications for enrollment trends are not clear. In fall 1998, 23\% of all first-time, first-year students who were enrolled in Title IV degree-granting institutions in Maryland were from other states; and 30\% of first-time, first-year, degree-seeking students who were residents of Maryland enrolled in institutions outside of the state (Morgan, 2001). Second, only 15 of the 20 community colleges that reported fall enrollment data for 1994, 1996, and 1998 also reported data for 2000. Because of the magnitude of missing data, we did not examine enrollment in community colleges in fall 2000.

The analyses are descriptive only and focus on trends in one state during one period in time. Differences in economic, political, social, and historical contexts (Callan, 2002) restrict the generalizability of the findings to other states and other points in time. The study is also limited to an examination of state public policies, ignoring changes in institutional and federal policies as well as legal and political forces. Focusing on state policies responds to Michael Mumper's (2001) argument that the state, not the federal, government has primary responsibility for ensuring equity in postsecondary educational opportunity.

\section{The State Context}

Maryland is an important state for exploring the relationship between racial/ethnic stratification of college enrollment and state public policies 
for at least three reasons. First, Maryland supports a diverse system of higher education, comprised of 13 public four-year institutions, 16 public twoyear institutions, 26 private four-year institutions, and 2 private two-year institutions. Of the 13 public four-year institutions, four are historically black colleges and universities (HBCUs). The state provides unrestricted direct institutional aid to both public and private higher education institutions. Established in 1971, the Joseph A. Sellinger State Aid Program provides state aid to private colleges and universities. To be eligible for funding, an institution must be an accredited, state-approved, nonprofit college or university, must have been established in Maryland prior to July 1970, and must award associate or bachelor's degrees in areas other than seminary and theology. A formula that considers FTE enrollments at independent institutions and per-student state aid at selected four-year public institutions determines the amount of aid allocated to independent institutions (Maryland Independent College and University Association [MICUA], 2003).

Second, as one of 19 states that once operated a dual system of public higher education, Maryland is required by the 1992 U.S. Supreme Court decision in U.S. v. Fordice to take affirmative steps to desegregate its public colleges and universities (Southern Education Foundation, 1998). At least in part because of pressure to desegregate higher education and challenges to the use of race-based financial aid programs (e.g., Podbereksy v. Kirwan, 1995), some (Rawlings \& Ards, 1997) have observed that Maryland has worked since at least 1985 to reduce disparities in college access in the state.

Despite such efforts, however, at least two reports (Southern Education Foundation, 1998; State Higher Education Executive Officers, 1997) conclude that Maryland (as well as other states) has not achieved equity in postsecondary education. Educational attainment in Maryland continues to vary by race/ethnicity, with higher average educational attainment among Asian and White residents than among Hispanic and Black residents. In 2000, 55\% of Asians and 35\% of Whites age 25 and older held at least a bachelor's degree, compared with only $21 \%$ of Hispanics and $20 \%$ of Blacks (Maryland Department of Planning, 2002).

Third, in 1988 the state passed legislation (Chapter 245, Acts of 1988) that emphasized promoting college access for economically disadvantaged and African American students (Rawlings \& Ards, 1997; Task Force, 1999). The legislation replaced the State Board for Higher Education with a new statewide coordinating entity, the Maryland Higher Education Commission (MHEC). (See Berdahl and Schmidtlein, 1996, for a discussion of the restructuring.) Among MHEC's legislated responsibilities are promoting desegregation and equal educational opportunity and managing statewide student financial aid programs. The legislation also called for improving the state's HBCUs and increasing state financial support for higher education (Task Force, 1999). 


\section{Enrollment Trends}

Analyses of the IPEDS annual Fall Enrollment Surveys show that the number of first-time, full-time freshmen enrolled in four-year and public two-year colleges and universities in Maryland increased by $26 \%$ between fall 1990 and fall 1998. Table 1 shows that enrollment grew faster during the 1990s among non-Whites than Whites. Between 1990 and 1998, the number of first-time, full-time freshmen enrolled in Maryland state-supported two-year and four-year colleges and universities, a measure of college access, increased by $10 \%$ for Whites, but $74 \%$ for American Indian/Alaskan Natives, $40 \%$ for Asians, $48 \%$ for Blacks, and 72\% for Hispanics.

While college access appears to have increased during the 1990s, higher education opportunity in Maryland continues to be stratified by race/ ethnicity. Although the total rate of increase in enrollments between 1990 and 1998 was greater for Blacks than for Whites (48\% versus 10\%), Blacks continue to be underrepresented among college enrollments relative to their representation in the eligible population. Specifically, Blacks represented a higher share of high school completers in 1997-1998 (31\%) than of firsttime, full-time freshmen in the state in fall 1998 (25\%). Hispanics represented about $3 \%$ of both high school completers and first-time, full-time undergraduates in 1998.

Higher education in Maryland is also stratified by race/ethnicity in terms of the type of institution attended (i.e., choice), as illustrated by the continued underrepresentation of Blacks at all types of state-supported institutions except HBCUs. Table 1 shows that Blacks are most severely underrepresented at private, state-supported, four-year institutions and at public four-year non-HBCUs, representing only $9 \%$ and $11 \%$, respectively, of first-time, full-time freshmen in 2000. More than one-third (38\%) of the state's Black first-time, full-time freshmen attended HBCUs in fall 1998.

Racial/ethnic stratification in college choice increased during the 1990s, as suggested by differential rates of growth at different types of institutions. The rate of increase between 1990 and 2000 in Black first-time, full-time freshmen was faster at the state's HBCUs $(41 \%)$ than at the state's other public four-year institutions (7\%) and at the state-supported private fouryear institutions (39\%). Between 1990 and 1998, enrollment rates also increased faster at the state's public two-year institutions than at the state's public four-year non-HBCUs and state-supported, private four-year institutions among Hispanics (106\% versus 63\% and 22\%) and Blacks (79\% versus $17 \%$ and $35 \%)$. In contrast, among Whites, the rate of increase in first-time, full-time enrollments was greater at public four-year, non-HBCUs and state-supported private four-year institutions than at public two-year institutions ( $22 \%$ increase and $17 \%$ increase versus $4 \%$ decline). Because of these differential growth rates, the share of Black first-time, full-time fresh- 


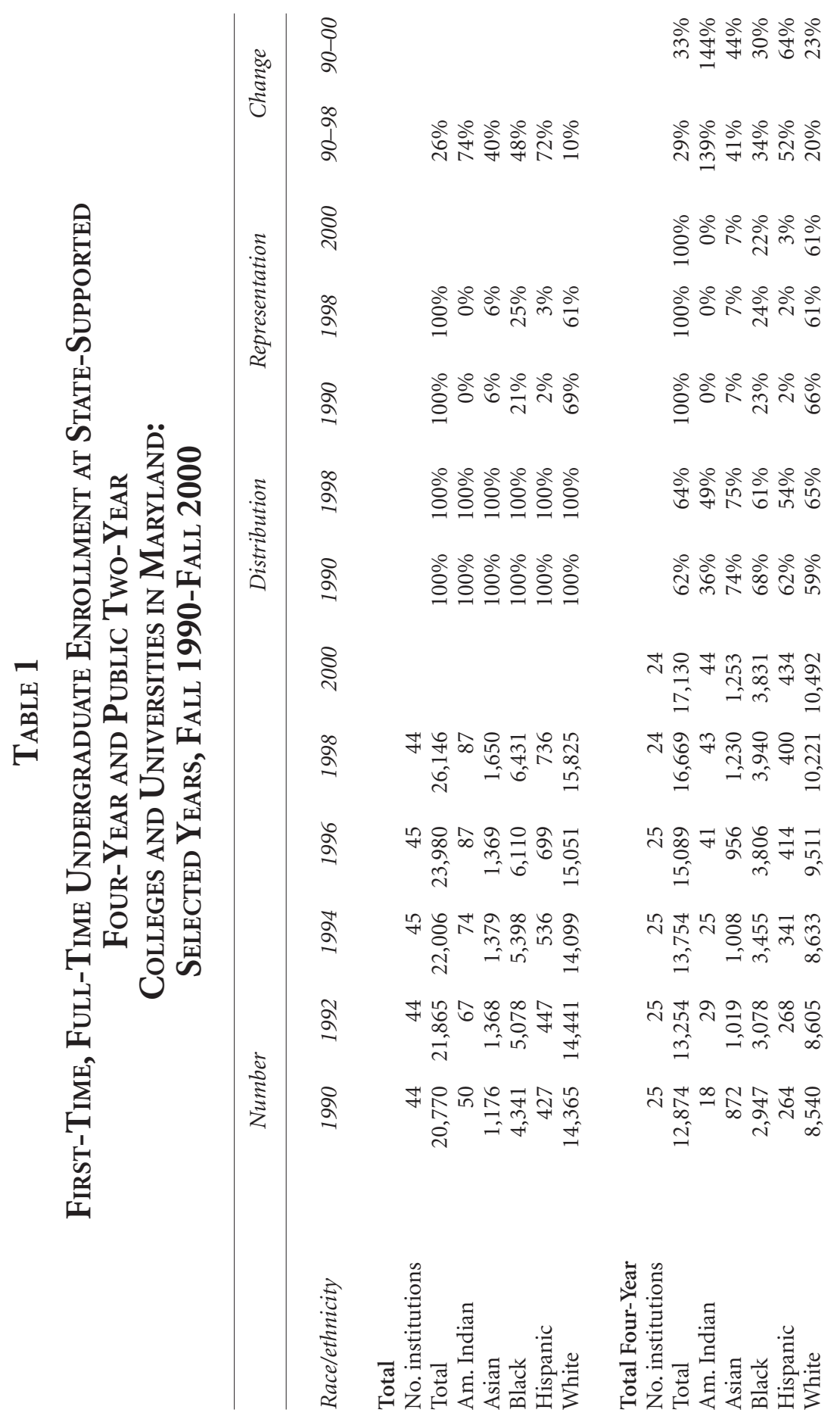




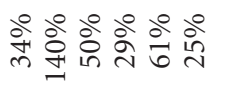

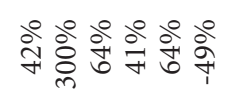

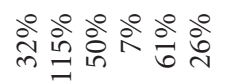

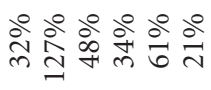

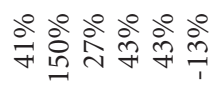

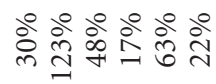

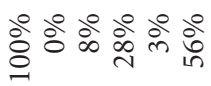

ธิํํㅇํำ ㅇำ

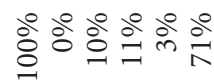

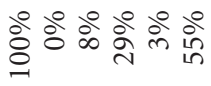

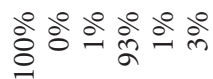

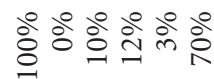

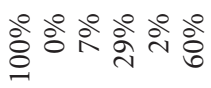

ธิํํㅇํำㅇำ

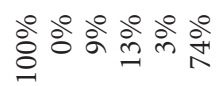

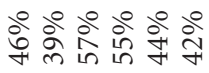

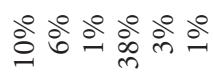

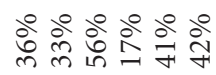

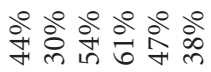

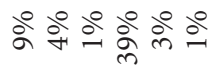

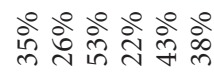

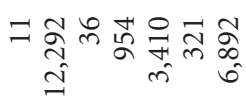

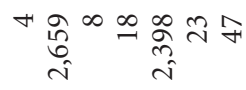

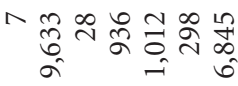

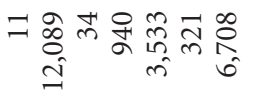

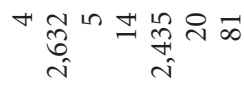

^帒

$=$ ก

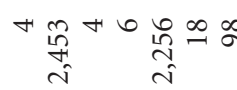

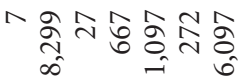

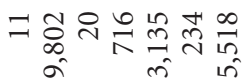

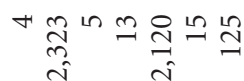

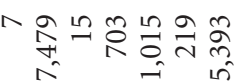

च

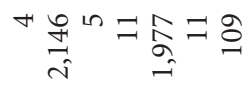

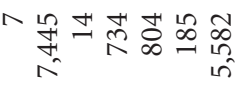

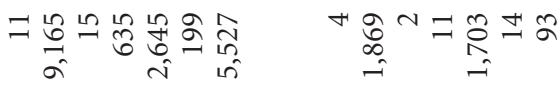

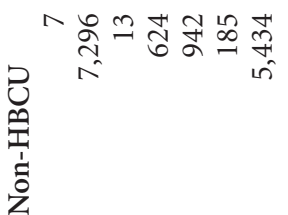

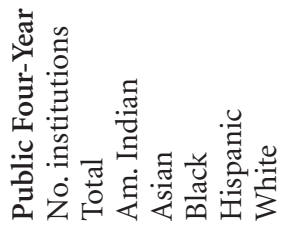

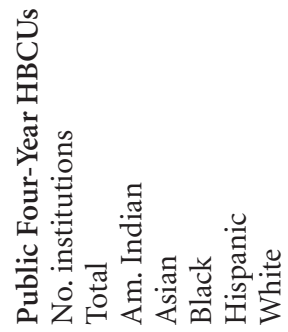

节 


\begin{tabular}{|c|c|c|c|c|}
\hline \multirow{2}{*}{ : } & \& & 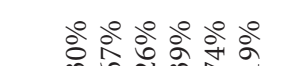 & \multirow[b]{2}{*}{ bㅇㅇㅇㅇㅇㅇ } & \multirow{3}{*}{ 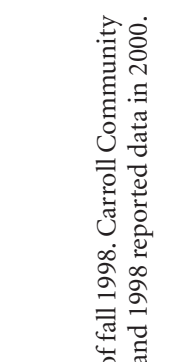 } \\
\hline & $\stackrel{\infty}{i}$ & 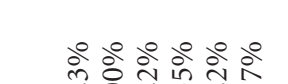 & & \\
\hline 㳯 & 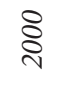 & 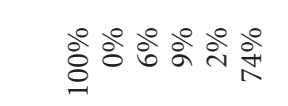 & & \\
\hline 密 & $\stackrel{\infty}{2}$ & 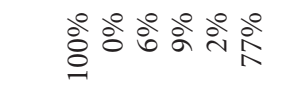 & 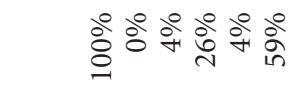 & \\
\hline & $\stackrel{2}{2}$ & ठిㅇㅇㅇㅇ & 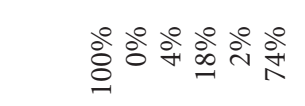 & \\
\hline 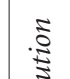 & $\stackrel{\infty}{2}$ & & 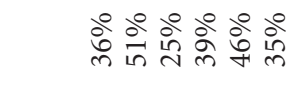 & \\
\hline 竞 & ఏ & ஓे & 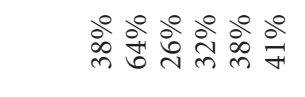 & \\
\hline & ఏ్ & 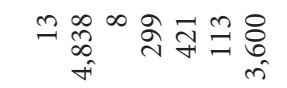 & & \\
\hline & $\stackrel{\infty}{\circ}$ & mascos & 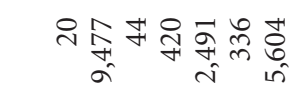 & \\
\hline & $\stackrel{2}{2}$ & 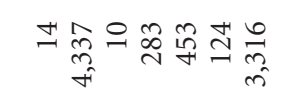 & 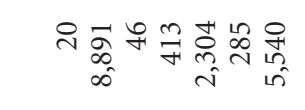 & \\
\hline & 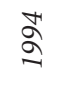 & 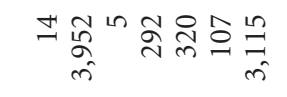 & 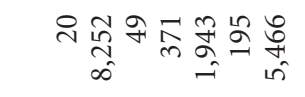 & \\
\hline & ลू & ت & ح. & \\
\hline है & $\stackrel{2}{2}$ & 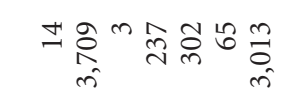 & Эa & \\
\hline & 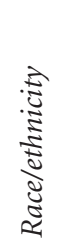 & 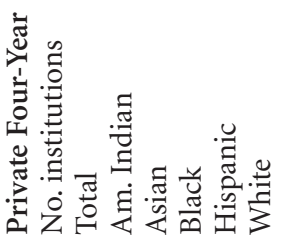 & 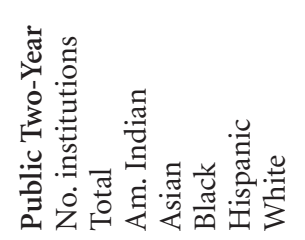 & 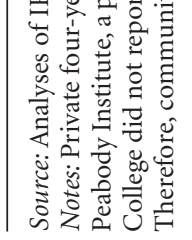 \\
\hline
\end{tabular}


men attending a public four-year non-HBCU declined from $22 \%$ in 1990 to $17 \%$ in 1998 , while the share of White first-time, full-time freshmen attending a public four-year non-HBCU increased from 38\% in 1990 to 42\% in 1998.

\section{Demand-Side Sources of Changes in College Enrollment Patterns}

\section{High School Completions}

One source of the overall increase in college enrollment during the 1990s was an increase in the college-eligible population, i.e., high school graduates. Between 1992 and 1998, the number of high school completers increased by $13 \%$. The rate of increase in high school completers from 1992 to 1998 varied by racial/ethnic group, ranging from $2 \%$ for Whites, to $18 \%$ for Asians, $32 \%$ for Blacks, and 60\% for Hispanics. The increase in the number of Black high school completers appears to be due primarily to an increase in the Black population in the state, as the four-year high school completion rate for Blacks did not increase over this period: 73\% in 1995 and $71 \%$ in 1998 (Young \& Hoffman, 2002). In contrast, the increase in Hispanic high school completers appears to be due, in part, to an increase in high school completion rates, which rose from $61 \%$ in 1995 to $80 \%$ in 1998 (Young \& Hoffman, 2002).

Donald Heller (1999) argued that participation rates should be calculated to control for differences in the relative size, and changes in the size, of each group. In this study, participation rates are the number of first-time, full-time freshmen relative to the number of high school completers in the previous academic year. For example, the participation rate for 1998 is the number of first-time, full-time freshmen enrolled in fall 1998 divided by the number of high school completers in the 1997-98 academic year.

A review of the participation rates (tables available on request) suggests an increase in the racial/ethnic stratification of college access during the 1990s. While the number of Black first-time, full-time freshmen enrolled in four-year and public two-year institutions in the state increased by $48 \%$ between 1990 and 1998 (Table 1), college participation rates for Blacks were actually slightly lower in 1998 than in 1992 (45\% versus 47\%). The gap between the college participation rates of Whites and Blacks grew from 8 percentage points in 1992 to 14 percentage points in 1998. While the Hispanic college participation rate fluctuated over the period, the rate was virtually the same in 1998 as in 1992 (50\% versus 49\%). The Hispanic-White gap in college participation rates grew from 6 percentage points in 1992 to 9 percentage points in 1998. 
Participation rates also show that the racial/ethnic stratification of college choice increased over this period. Most of the Black-White gap in college participation rates is accounted for by differences at public four-year non-HBCUs. At public four-year non-HBCUs, the Black-White gap in participation rates grew from 14 percentage points in 1992 to 18 percentage points in 1998. Most of the Hispanic-White gap is attributable to differences in participation rates at private, four-year institutions, where the Hispanic-White participation gap grew from 3 percentage points in 1992 to 8 percentage points in 1998.

\section{Tuition}

Economic theories of supply and demand predict that as tuition rises, enrollment declines (Paulsen, 2001a). Research shows that Black enrollments are more sensitive than White enrollments to changes in tuition (Heller, 1997; Paulsen, 2001a). As predicted, increases in tuition appear to be one cause of the increased racial/ethnic stratification of higher education access in Maryland during the 1990s. Average undergraduate tuition for Maryland residents increased during the 1990s at all types of Maryland institutions (MHEC, 2002). (See Table 2.) Over the same period, the gap in college participation rates between Whites and Blacks grew from 8 to 14 percentage points, as described above.

Differential tuition and fee charges may be a cause of the racial/ethnic stratification of higher education choice. Table 2 shows that, in 2000-2001, average in-state tuition and mandatory fees for full-time undergraduates in Maryland ranged from $\$ 2,340$ at community colleges, to $\$ 3,988$ at HBCUs, to $\$ 5,113$ at public four-year non-HBCUs, to $\$ 17,801$ at private four-year institutions. Table 1 shows that the representation of Blacks among firsttime, full-time freshmen is higher among the lower cost community colleges $(26 \%)$ than at the higher cost four-year institutions (22\%). Moreover, at four-year colleges and universities the representation of Blacks is inversely related to average tuition and fees. The representation of Blacks among firsttime, full-time freshmen in fall 2000 was highest at the lowest tuition HBCUs (90\%), next highest at the middle-tuition public four-year non-HBCUs (11\%), and lowest at the highest tuition private four-year institutions (9\%).

As predicted by economic theories of substitution (Paulsen, 2001c) and the greater sensitivity of Blacks than Whites to tuition increases (Heller, 1997; Paulsen, 2001a), differential rates of tuition increases by institutional type during the 1990s may have contributed to the increased racial/ethnic stratification of college choice. Table 2 shows that, after controlling for inflation, the percentage increases in tuition and fees between 1990-1991 and 2000-2001 ranged from 39\% at community colleges, to $44 \%$ at HBCUs, to $47 \%$ at state-supported private four-year institutions, to $62 \%$ at public fouryear non-HBCUs. Over the same period, college enrollment rates for Blacks 


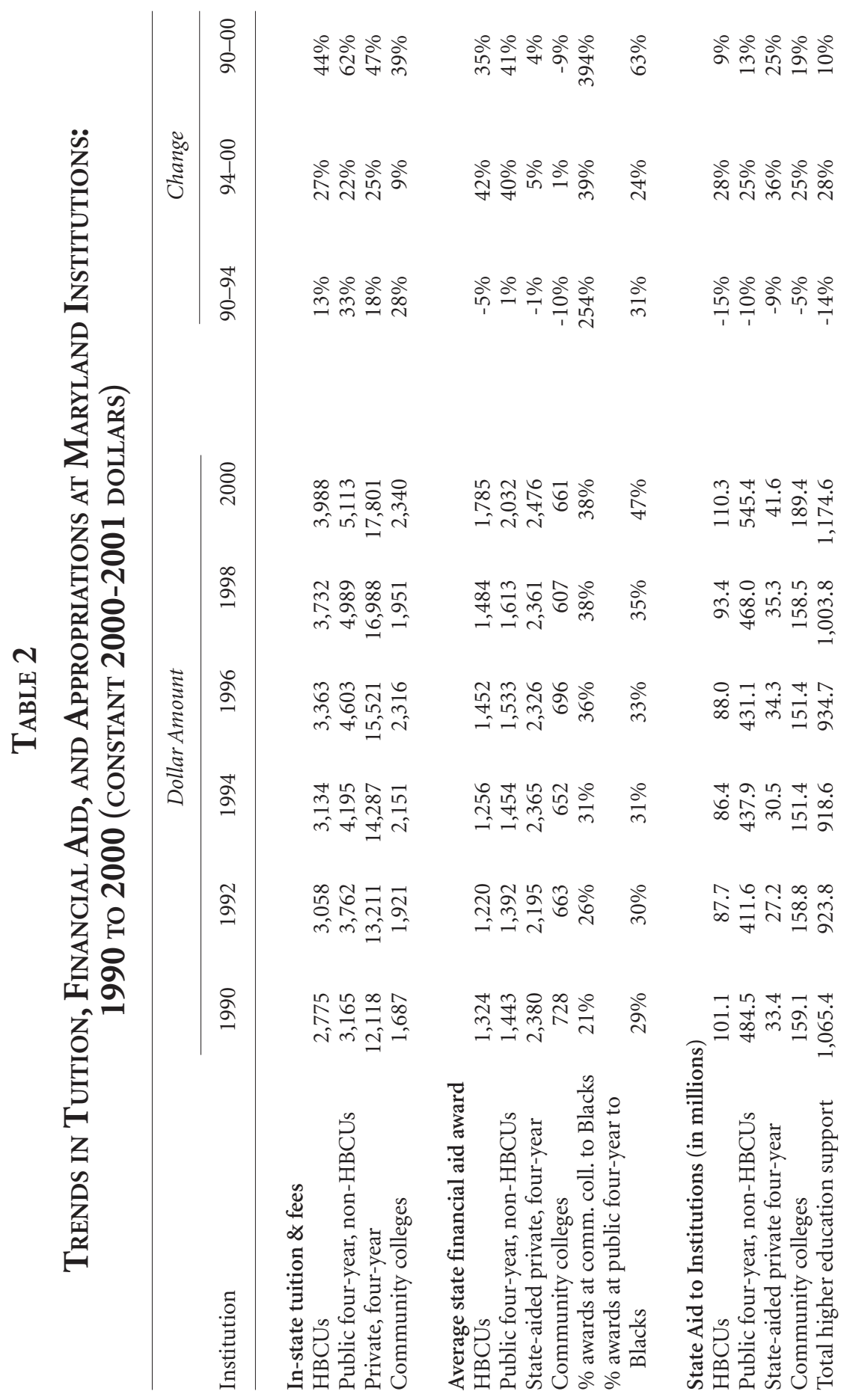


Table 2 Continued

Source: Analyses of MHEC (1992, 1994, 1996, 1998, 2000, 2002, 2003).

Notes: All figures except tuition and fees at private four-year colleges and universities are weighted by FTE enrollment at each institution. Because of data limitations, tuition and fees at private four-year colleges are the average across institutions. Tuition and fees for community colleges are the charges for residents of the service area. State aid reflects the general fund at public institutions and state aid grant at private institutions.

To increase comparability with the enrollment data, the data in this table describe the period that includes the fall of a given year. For example, "1990" describes the 1990-1991 academic year and fiscal year 1991. Current dollars are converted to constant 2000-2001 dollars using the formula specified by the College Board (2002).

grew fastest at community colleges (79\%) and HBCUs (41\%), the institutions with the lowest rate of tuition growth, and slowest at public four-year, non-HBCUs (7\%), the institutions with the highest tuition growth.

\section{Student Financial Aid}

For many students, the cost of attendance is reduced by financial aid. In the 2000-2001 academic year, 127,800 undergraduates at Maryland colleges and universities received more than $\$ 773$ million in student financial aid (MHEC, 2002). About $24 \%$ of this total was in the form of need-based federal, institutional, and private grants, $47 \%$ in federal and other loans, $19 \%$ in federal, institutional, and private scholarships, $2 \%$ in federal and institutional work-study, and $8 \%$ in state grants. While federal and other loans represented a higher share of undergraduate financial aid in FY2001 than in FY1991 (47\% versus 31\%) and need-based federal, institutional, and private grants represented a lower share (24\% versus $32 \%)$, state aid represented a comparable share: $8 \%$ versus $9 \%$ (MHEC, 1992, 2002).

Shifts in state student financial aid may have somewhat reduced the negative effects on racial/ethnic stratification of college access of the tuition increases that occurred during the 1990s. Specifically, the share of state financial aid dollars that was awarded to undergraduates based on financial need increased from $47 \%$ in $1990-1991$ to 55\% in 2000-2001 (MHEC, 1992, 2002). In 2000-2001, 55\% of all state financial aid dollars to undergraduates was awarded through need-based grant programs, $10 \%$ through legislative programs, $9 \%$ through merit-based programs, and 27\% through other programs, including service-based programs and programs for unique populations (MHEC, 2002).

Another indicator that state financial aid may have reduced the negative effects of tuition on racial/ethnic stratification of college access during the 1990 s is the growth in awards to Blacks. Table 2 shows that, between 19901991 and 2000-2001, the share of state financial aid awards to Blacks in- 
creased at community colleges from $21 \%$ to $38 \%$. The rate of increase over this period in the number of state financial aid awards to Blacks was substantially greater at community colleges than at public four-year colleges and universities (394\% versus 63\%). ${ }^{1}$ Following the same pattern, the rate of increase between fall 1990 and fall 1998 in Black first-time, full-time freshmen enrollment was greater at community colleges than at public fouryear institutions: $79 \%$ versus $29 \%$. (See Table 1.) The substantial growth in Black enrollment at community colleges occurred despite a $9 \%$ decline in constant dollars between 1990-1991 and 2000-2001 in the average state financial aid award at community colleges (See Table 2.)

The increased emphasis of state financial aid on need and the increased share of state financial aid awards to Blacks likely reduced the magnitude of the racial/ethnic stratification of college access that occurred in Maryland during the 1990s. Changes in relative amounts of state aid awards over this period may have also reduced the magnitude of the racial/ethnic stratification of college choice. Table 2 shows that, after controlling for inflation, the rate of growth in average state aid award was greater at public four-year non-HBCUs (41\%) than at HBCUs (35\%), private four-year colleges (4\%), and community colleges $(-9 \%)$. Nonetheless, the growth in state aid awards appears to have been insufficient to compensate for the negative effects of tuition on stratification. Despite the $41 \%$ increase in the average state aid award at public four-year non-HBCUs, these institutions, which have the highest rate of tuition growth (62\%) (Table 2), experienced the lowest rate of growth in Black first-time, full-time freshman enrollment (7\%) (see Table 1). The increase in the representation of Blacks among first-time, full-time freshmen at private four-year institutions from 8\% in 1990 to $9 \%$ in 2000 (Table 1 ) occurred despite the very small growth $(4 \%)$ in average state financial aid awards at these institutions (Table 2).

\section{The State Unemployment Rate}

Human capital theory predicts that an individual decides to enroll in college based on a comparison of the perceived benefits and costs, including the costs of foregone earnings. When unemployment is high, foregone earnings decline, and the opportunity costs of college enrollment fall (Paulsen, 2001b). Research shows that enrollment rates at public institutions, particularly two-year institutions, increase when the state unemployment rate rises (Heller, 1999; Kane, 1999) and that the enrollments of lower-income students are more sensitive than those of other students to changes in unemployment (Kane, 1999).

${ }^{1}$ Data limitations prohibit a separate examination of the race of recipients at HBCUs versus non-HBCUs or private colleges and universities. 
An increase in the unemployment rate may be a source of the increase in Black enrollment at community colleges in Maryland during the early 1990s. The unemployment rate for Blacks (including Hispanic origin) increased from $8.7 \%$ in 1990 to $11.2 \%$ in 1992 and then generally declined each year to $6.4 \%$ in 2000 (U.S. Department of Labor, 1990, 1992, 2000). The largest two-year increase in first-time, full-time enrollment at community colleges among Blacks occurred when unemployment was at its highest, between fall 1990 and fall 1992 (43\% increase in first-time, full-time Black enrollment). White enrollment at community colleges does not appear to be related to changes in the unemployment rate, perhaps due in part to the lower rates of unemployment for Whites than Blacks in any given year.

\section{Supply-Side Sources of Changes in College Enrollment Patterns}

\section{State Appropriations}

One supply-side intervention is direct, unrestricted appropriations to higher education institutions in the state. No state law guarantees a minimum level of support to Maryland's colleges and universities (Department of Legislative Services, 1998). Nonetheless, legislation passed in both 1988 and 1998 expresses policymakers' support for adequate state funding for higher education by recommending a floor of funding for public and private colleges and universities, MHEC, and student financial aid programs "barring unforeseen economic conditions" (Task Force, 1999).

Yet because of "unforeseen economic conditions" (i.e., recession) during the early 1990s, state appropriations to higher education were below legislated targets (Task Force, 1999). In response to the fiscal crisis, the state took cost-containment actions that caused reductions after the beginning of FY1991, FY1992, and FY1993 (Department of Fiscal Services, 1995). Table 2 shows that, after controlling for inflation, total appropriations to higher education declined by 14\% between FY1990 and FY1994 (from \$1,065.4 million to $\$ 918.6$ million in constant 2000-2001 dollars). Reflecting the promise of Governor Parris Glendening to make higher education a top budget priority (Department of Legislative Services, 1999), state appropriations increased during the mid- to late-1990s, rising by $28 \%$ in constant dollars between FY1994 and FY2000 (USM Office of Administration and Finance, 2003).

At public four-year non-HBCUs, changes in state appropriations during the 1990s appear to be linked to changes in tuition. Table 2 shows that, between 1990-1991 and 2000-2001, state appropriations to public fouryear non-HBCUs increased by $13 \%$ in constant dollars, a slower rate of increase than at private four-year (25\%) and community (19\%) colleges. Over the same period, tuition increased at a faster rate at public four-year 
non-HBCUs (62\%) than at all other types of institutions. The lower rate of increase in appropriations and higher rate of increase in tuition at public four-year non-HBCUs likely contributed to the increased gap in Black-White participation rates at this type of institution.

State-aided private four-year colleges and universities experienced the fastest rate of increase in state appropriations during the 1990s: $25 \%$ in constant 2000-2001 dollars (Table 2). This growth may have contributed to the lower rate of increase in tuition for this sector than for public four-year non-HBCUs ( $47 \%$ versus $62 \%$ in constant dollars) over this period. Nonetheless, the higher rate of increase in state appropriations at state-aided private four-year institutions appears to have had minimal impact on Black enrollment at these institutions, as the representation of Blacks among firsttime full-time freshmen increased marginally from $8 \%$ in fall 1990 to $9 \%$ in fall 2000 (Table 1).

The relationships among state appropriations and tuition at public fouryear HBCUs are counterintuitive. Table 2 shows that public four-year HBCUs experienced the smallest rate of growth in state appropriations between 1990-1991 and 2000-2001 (9\% increase in constant dollars). Despite receiving the lowest rate of increase, HBCUs also sustained lower tuition growth (44\%) than other four-year institutions during this period. At the same time, Black first-time, full-time freshmen enrollment grew faster (41\%) at HBCUs than at other four-year institutions (Table 1). These relationships suggest the strong positive effects on college access of low tuition.

Among public institutions, community colleges experienced the highest rate of increase in state appropriations during the 1990s: 19\% in constant dollars (Table 2). The rate of increase for community colleges, which is higher than for other public institutions, may reflect, at least in part, a change in the state funding formula for community colleges. In 1991 the General Assembly passed legislation (House Bill 204), effective FY1993, that was designed to reduce community colleges' dependence on tuition as a source of revenue (Department of Legislative Services, 1991). This goal appears to have been at least partially achieved, as community colleges experienced a lower rate of tuition growth (39\%) than other sectors during this period. The finding that community colleges experienced the highest rate of growth (a 79\% increase) in Black first-time full-time freshmen during the 1990s (Table 1) may be attributable to the higher growth in appropriations and the lower growth in tuition than other sectors.

\section{Desegregation Initiatives}

Desegregation initiatives are an additional supply-side intervention. During the 1990s, however, desegregation policies in Maryland appeared to involve not much more than MHEC's "monitoring" of the efforts undertaken by the state's public institutions to increase access for Blacks. Although the state passed legislation in 1988 that required MHEC to create a plan to 
enhance the state's four HBCUs, the Task Force on the Governance, Coordination, and Funding of the USM (1999) concluded that MHEC did not develop a program of desegregation or a plan for enhancing the HBCUs until 1998. As part of an October 1999 "Partnership Agreement" with OCR, MHEC promised to enhance HBCUs so as to provide equal opportunities for students who attend them, to increase enrollment of non-Blacks at HBCUs, support efforts to increase the recruitment of students at traditionally White institutions (TWIs), and to raise the amount of need-based financial aid available at TWIs. In the late 1990s, MHEC provided grants to HBCUs to develop and implement recruitment and retention initiatives. For example, the Access and Success program provided \$500,000 in FY1999 and $\$ 750,000$ in FY2001 to each of the four HBCUs. Because of the timing, however, these initiatives likely had minimal impact on the racial/ethnic stratification of college enrollment in the state during the 1990s.

\section{Summary}

This exploration of the relationship between state public policies and college enrollment shows the increase in the racial/ethnic stratification of college access and choice during the 1990s in Maryland despite the presence of public policies intended to influence both the demand for and supply of higher education in the state. The relative importance of different public policies to enrollment stratification appears to vary by sector. At public four-year non-HBCUs, the increased Black-White gap in participation appears to be linked to the lower rate of growth in state appropriations and higher rate of growth in tuition relative to other types of institutions in the state. Although average state financial aid awards also increased faster at public four-year non-HBCUs than at other types of institutions, this increase did not sufficiently compensate for the negative effects of tuition on racial/ethnic stratification.

Blacks continued to be relatively concentrated in the state's public fouryear HBCUs during the 1990s. The faster rate of growth in enrollment at HBCUs than at other types of four-year institutions appears to be attributable, at least in part, to the relatively lower rate of growth in tuition, despite a lower rate of growth in state appropriations, for this sector.

At private four-year institutions, the relatively high rate of growth in state appropriations may have contributed to a lower rate of growth in tuition and faster rate of growth in Black enrollment for this sector than for public four-year non-HBCUs. At private four-year institutions, as well as public four-year non-HBCUs, changes in state financial aid appear to have had a smaller effect on Black enrollment than tuition. During the 1990s, the representation of Blacks increased from $8 \%$ to $9 \%$ at private four-year institutions but declined from $13 \%$ to $11 \%$ at public four-year non-HBCUs, despite a substantially smaller rate of increase in average state financial aid awards at private than at public four-year non-HBCUs. 
Blacks became increasingly segregated in the state's community colleges during the 1990s. This trend seems attributable, at least in part, to Blacks' sensitivity to the opportunity costs of college enrollment (as measured by unemployment rates) and the relatively high rate of growth in state appropriations and relatively low rate of growth in tuition for this sector. The positive effects on enrollment of the state's increased emphasis on need in awarding financial aid and increased shares of awards to Blacks appears to have offset the negative effects of the real decline in average state financial aid awards to community college students during the 1990s.

\section{Projections for Racial/Ethnic Stratification in Maryland Based on Post-1990s Policies}

Perhaps even more troubling than the increase in the racial/ethnic stratification of college access and choice during the 1990s in Maryland are the potential negative impacts of state policies that were established in the late 1990s and early 2000s. The current racial/ethnic stratification in Maryland is likely to grow, at least in the short-term, with the implementation of more rigorous high school graduation requirements, a reduction in state appropriations to higher education institutions, increases in tuition, the absence of a strong commitment to need-based financial aid, and a projected increase in the demand for higher education without a simultaneous increase in the available supply.

\section{More Rigorous High School Graduation Requirements}

One state policy that may improve the academic preparation of students for college in the long term but reduce the shares of Blacks and Hispanics who are eligible to attend college in the short term is the implementation of the high school assessments as a requirement for graduating from high school. Maryland high school students must now pass basic skills tests in reading, math, writing, and citizenship (State Board of Education, 1996). The high school assessments are expected to replace the functional tests as a graduation requirement beginning with students who enter ninth grade in fall 2005 (Grasmick, 2003). While the functional tests assessed basic skills and functional knowledge, the high school assessments evaluate "core learning goals" through end-of-course exams.

Racial/ethnic group differences in pass rates suggest that, at least in the short-term, the new tests may reduce the ratio of Black students who are eligible to attend college. In 2003, only $20 \%$ of Black seventh graders, but $44 \%$ of all seventh graders, passed the English component of the high school assessments that they must pass to graduate from high school on schedule in 2009 (Perlstein, 2004).

Increasing high school graduation requirements and other state and federal K-12 educational reform efforts may ultimately ensure that more stu- 
dents are academically prepared to enroll in and graduate from college. Nonetheless, policymakers must work to reduce any unintended consequences of such policies, including pushing less prepared students-students who are disproportionately low-income, Black, and Hispanic-out of the educational system (Perna, in press; Sireci et al., 2003).

\section{Reduced State Appropriations and Increased Tuition}

In 1998 the state legislature (Chapter 619, Senate Bill 596) recommended that the governor's annual budget for higher education be no less than the amount appropriated in the previous year (Department of Legislative Services, 1998). The legislation also set a goal of allocating $12.5 \%$ of the state's general fund revenues to higher education in FY2000 with incremental increases thereafter so that, by FY2004, 15.5\% of general fund revenues would be allocated to higher education (Department of Legislative Services, 1998; Task Force, 1999). Nonetheless, the state legislature reduced FY2003 appropriations to public universities by 3.5\% and proposed an FY2004 budget that was $7.5 \%$ lower than the FY2003 revised appropriation (Department of Legislative Services, 2003).

State appropriations are unlikely to reach the targeted levels in the near future, given the conclusion by state policymakers that "higher education institutions have access to significant alternative sources of revenue," e.g., tuition (Department of Legislative Services, 2003, p. 7), and that institutions need to "achieve real spending reductions" (Department of Legislative Services, 2003, p. 12). In addition to a change from a Democratic, pro-higher education governor to a Republican, pro-tax-cut governor in 2002, prospects for future state funding for higher education are also dimmed by fiscal pressures that are occurring in other states, including the presence of structural budget deficits, increased competition for state resources for health care, prisons, and $\mathrm{K}-12$ education, and the need to balance the state budget (Hovey, 2001; Mumper, 2001).

In Maryland, competition for state resources may further intensify with implementation of the "Thorton bill" (i.e., Chapter 288 of 2002). The law replaces the "current expense formula" for K-12 education with the "foundation formula," which, effective FY2004, requires a minimum per-student funding level (MSDE, 2002a). The law also requires additional funding beginning in FY2004 for compensatory education, special education, school bus transportation, and limited English proficiency. Although the funding mandates in this law may improve the academic preparation and readiness of $\mathrm{K}-12$ students for college, the mandates also reduce the availability of state resources for such "discretionary" budget items as higher education.

State policymakers should work to realize the goal of maintaining a "floor" of funding for the state's higher education institutions even in the context of "unforeseen economic circumstances." This study suggests that maintaining adequate state appropriations is especially important for ensuring 
affordability of the state's public four-year non-HBCUs. In its most recent 10-year strategic plan, the USM Board of Regents (2000) concluded that undergraduate tuition for state residents is currently "moderate" relative to in-state undergraduate tuition at research universities in neighboring states and at the lower end of "high" relative to in-state undergraduate tuition at comprehensive institutions in neighboring states.

Other organizations paint a less rosy picture of the affordability of the state's higher education institutions. On its state-by-state report card, the National Center for Public Policy and Higher Education (2002) awarded Maryland a "D-" on indicators of "affordability." Kipp and colleagues (2002) categorized Maryland as one of 22 states that is "least consistently accessible" to low- and median-income dependent students without borrowing. Achieving the targeted level of state appropriations to higher education institutions will require policymakers to commit to funding higher education regardless of the strength of the state's economy. By reducing the volatility of state appropriations to higher education, policymakers may encourage a more reasonable and predictable pattern of annual tuition increases.

\section{No Strong Commitment to Need-Based Student Financial Aid}

The USM Board of Regents (2000) pledged in its 10-year strategic plan to match tuition increases with increases in financial aid. Although the share of state aid that is allocated based on financial need increased during the 1990s, other indicators, including the racial/ethnic stratification patterns identified in this study, suggest that the state's attention to need-based financial aid is inadequate. According to Measuring Up 2002, Maryland's indexed score for need-based financial aid in 2002 was 39 out of 100, where 100 reflects need-based aid for the best performing state (National Center for Public Policy and Higher Education, 2002).

The extent to which the state's financial aid programs will be influenced by political pressures to increase the share of state aid that is awarded based on merit rather than financial need is unclear. Nationwide, state funding has increased faster for merit-based financial aid programs than for needbased since the mid-1990s (Heller, 2002). Like other states (e.g., Alabama, Florida, Georgia, Kentucky, Louisiana, Michigan, New Mexico, Texas, and Washington), Maryland has implemented merit-based financial aid programs (Heller, 2002). Effective October 1, 2000, the Maryland HOPE Scholarship Program provides annual scholarships of $\$ 3,000$ for undergraduates at four-year institutions and $\$ 1,000$ for undergraduates at two-year institutions. To be eligible, a student must be a Maryland resident, attend a bachelor's or associate degree granting program, enroll full-time in higher education within two years of graduating from high school, have an annual family income no higher than $\$ 95,000$, and earn a minimum GPA of 3.0. The program is designed, in part, to reduce brain drain, as recipients are 
required to work full-time in Maryland one year for each year of the grant or to repay the aid with interest.

In contrast to the national trend, Governor Robert Ehrlich's FY2005 budget proposes shifting $\$ 4$ million from state programs that award financial aid based on merit to those that make awards based on financial need (Ehrlich, Steele, \& DiPaula, 2004). But the extent to which the legislature will support the proposal is not yet clear. Reducing racial/ethnic stratification in college access and choice requires policymakers to recognize that state-sponsored merit-based financial aid programs do not promote college access but rather divert scarce resources away from groups that have been historically underrepresented in higher education (Hearn, 2001; Mumper, 2001).

State-sponsored college savings plans also divert scarce public resources toward middle- and upper-income families and away from students from traditionally underrepresented groups (Callan, 2002; Mumper, 2001). Like other states (Roth, 2001), Maryland established a prepaid tuition plan and a college savings plan in the late 1990s. Established in 1997, the Maryland Prepaid College Trust allows residents of Maryland and the District of Columbia to prepay tuition and fees over a period of time in order to lock in the price of future tuition and fees. The program guarantees the payment of in-state tuition and fees for children who attend a Maryland public college and a weighted average tuition at Maryland public colleges for children who attend an eligible private or out-of-state institution (Department of Legislative Services, 1998, 1999; Maryland General Assembly, 2003). Established in 2000, the Maryland College Tuition Savings Plan allows an individual to select one of 10 different investment portfolios and the amount and frequency of contributions. Individuals may use the contributions and investment earnings to pay the costs of tuition, fees, room, board, and other expenses. Although the state does not guarantee a return on the investment, participants benefit from federal and state tax advantages (Maryland General Assembly, 2003).

Little is known empirically about the impact of these programs on the racial/ethnic stratification of college access and choice. But these programs will likely exacerbate rather than narrow current gaps. Because of their lower average family incomes, Blacks and Hispanics likely have less disposable income to invest in, and thus benefit from, these programs. In 1999 median household incomes in the state ranged from $\$ 41,652$ for Blacks and $\$ 48,257$ for Hispanics to $\$ 58,005$ for Whites and \$59,589 for Asians (Maryland Department of Planning, 2002).

The state should also examine the extent to which maintaining a large number of small and narrowly targeted financial aid programs contributes to the state's goal of ensuring access to college for all students (Mumper, 2001). Effective FY1996, the state restructured its student financial aid pro- 
grams via the Scholarship Reform Act of 1991 (Senate Bill 207/House Bill 216, Department of Legislative Services, 1991; Task Force, 1999). The legislation replaced the General Scholarship Program with the Educational Excellence Award Program, a program that eliminated the consideration of a student's legislative district or test scores from eligibility criteria (Task Force, 1999). In the early 1990s the state consolidated scholarship programs for veterans, prisoners of war, and public safety personnel who died on duty into one program, consolidated five manpower programs into one Economic Development Student Assistance Grant program, and conducted a year-long study of state aid programs (Department of Legislative Services, 1990, 1991).

However, the state should again reexamine its financial aid programs in light of its goals and other higher education policies. Changing existing programs is not simple, as evidenced by repeated failed attempts to eliminate the state's legislative scholarship programs (Department of Legislative Services, 1992, 1993, 1994, 1995). Nonetheless, such an examination may assist the state with reconfiguring state aid programs to more effectively reduce the racial/ethnic stratification of college access and choice by shifting at least some scarce state resources from non-need-based programs to need-based aid programs (Institute for Higher Education Policy, 2002).

\section{Insufficient Supply of Higher Education}

The racial/ethnic stratification of higher education access and choice will also likely increase over the coming decade as the state faces a demand for higher education that exceeds the available supply. The supply of higher education in the state may decline as institutions respond to declining or stable state appropriations at least in part by reducing the number of available enrollment slots. At the same time, the demand for higher education in the state will likely increase due to population growth and $\mathrm{K}-12$ reform efforts. The Maryland Office of Planning (USM Board of Regents, 2000) projects that the number of 15 - to 24 -year olds in the state will grow by $27 \%$ between 2000 and 2010, resulting in 7,600 more full-time undergraduate students demanding to attend USM institutions, an increase in demand that exceeds current capacity of enrollment slots by 2,300 (USM Board of Regents, 2000). As in other states (Callan, 2002), the rate of growth in the 15- to 24-year old minority population in the state is projected to exceed the rate of growth in the White population: $32 \%$ versus $24 \%$ (USM Board of Regents, 2000). The demand for higher education may also increase due to growth in nontraditional student enrollment (Mumper, 2001).

$\mathrm{K}-12$ school reforms may also result in an increased demand for higher education. In 1995 the state formed the Maryland Partnership for Teaching and Learning K-16 to increase collaboration between K-12 and higher education (Shapiro, 2003). Comprised of the chief executive officers of the USM, 
MSDE, and MHEC, the partnership has three goals: (a) to increase access to college for disadvantaged and minority students by aligning high school and college requirements, (b) to enhance teacher quality and quantity, and (c) to improve communication and collaboration among the three partner organizations (Shapiro, 2003). Work to date has focused on establishing processes for addressing difficult issues including simultaneous pressures to increase both the quantity and quality of teachers, differential requirements on four-year institutions versus public schools regarding professional development schools, public pressure to increase the role of community colleges in alleviating the shortage of qualified teachers, and the implications for remediation that are associated with new statewide assessments (Shapiro, 2003). As the Southern Education Foundation (1998) observed, initiatives like Maryland's K-16 Partnership that are designed to build linkages between $\mathrm{K}-12$ schools and higher education may be especially effective at increasing college access and choice for Black students since these students are disproportionately represented in the lowest quality schools.

Population growth as well as programs that improve students' academic preparation for college will likely increase the demand for higher education in the state. However, policymakers must recognize that, if the supply of enrollment slots does not also increase or even decreases in response to reduced or flat state appropriations, then the racial/ethnic stratification of college access and choice is unlikely to decline. Economic theories of supply and demand suggest that higher education institutions will respond to the over-demand for higher education by raising the sticker price, an action that disproportionately reduces enrollment among students from historically underrepresented groups. An excess demand for higher education may also raise the level of competition for the available enrollment slots at all types of institutions in the state's higher education system. Students with the fewest financial, academic, and other resources, e.g., Blacks and Hispanics, will be the least successful in an increasingly competitive college enrollment environment.

\section{Conclusion}

One of the stated goals of the USM Board of Regents (2000) is to eliminate racial, ethnic, and income gaps in access to a USM institution by 2010. This study illustrates that racial/ethnic stratification of college access and choice increased in Maryland during the 1990s and describes the challenges that the state faces in reducing this stratification. Such stratification persists despite desegregation mandates and other policies that are designed to influence the supply of and demand for higher education in the state. In the context of these persisting gaps and the projected growth in the minority population in the state, Maryland policymakers (and policymakers in other 
states that are experiencing similar challenges) should understand the extent to which the state's higher education system is now stratified, consider the consequences of current trends in state public policies, and work to refocus resources in ways that effectively promote postsecondary educational opportunity for all state residents.

\section{REFERENCES}

Berdahl, R., \& Schmidtlein, F. (1996). Restructuring and its aftermath: Maryland. In T. J. MacTaggart and Associates (Eds.), Restructuring higher education: What works and what doesn't in reorganizing governing systems. San Francisco: JosseyBass Publishers.

Cabrera. A. F., LaNasa, S. M., \& Burkham, K. R. (2001). Pathways to a four-year degree: The higher education story of one generation. State College: Pennsylvania State University, Center for the Study of Higher Education.

Callan, P. M. (2002). Coping with recession: Public policy, economic downturns, and higher education. Washington, DC: National Center for Public Policy and Higher Education.

College Board. (2002). Trends in student aid: 2002. New York: Author.

Department of Fiscal Services. (1995). Major fiscal issues: 1991-1994. Annapolis, MD: Author.

Department of Legislative Services. (1990). Session review of the General Assembly 1990. Annapolis, MD: Office of Policy Analysis.

Department of Legislative Services. (1991). Session review of the General Assembly 1991. Annapolis, MD: Office of Policy Analysis.

Department of Legislative Services. (1992). Session review of the General Assembly 1992. Annapolis, MD: Office of Policy Analysis.

Department of Legislative Services. (1993). Session review of the General Assembly 1993. Annapolis, MD: Office of Policy Analysis.

Department of Legislative Services. (1994). Session review of the General Assembly 1994. Annapolis, MD: Office of Policy Analysis.

Department of Legislative Services. (1995). Session review of the General Assembly 1995. Annapolis, MD: Office of Policy Analysis.

Department of Legislative Services. (1998). Ninety day report: A review of legislation in the 1998 session. Annapolis, MD: Office of Policy Analysis.

Department of Legislative Services. (1999). Ninety day report: A review of legislation in the 1999 session. Annapolis, MD: Office of Policy Analysis.

Department of Legislative Services. (2003). Higher education: Fiscal 2004 budget overview. Annapolis, MD: Office of Policy Analysis.

Ehrlich, R. L., Steele, M. S., DiPaula, J. C. (2004). Maryland fiscal year 2005 budget: Budget highlights. Annapolis, MD: Department of Budget and Management.

Grasmick, N.S. (2003). Letter from the State Superintendent to parents. Maryland State Department of Education. Retrieved January 2004 from www.mdk12. org/mspp/.

Hansen, W. L., \& Weisbrod, B. A. (1969). Benefits, costs, and finance of public higher education. Chicago: Markham Publishing. 
Hearn, J. C. (2001). Access to postsecondary education: Financing equity in an evolving context. In M. B. Paulsen and J. C. Smart (Eds.), The finance of higher education: Theory, research, policy, and practice (pp. 439-460). New York: Agathon Press.

Heller, D. E. (1997). Student price response in higher education: An update to Leslie and Brinkman. Journal of Higher Education, 68(6), 624-659.

Heller, D. E. (1999). Racial equity in college participation: African American students in the United States. Review of African American Education, 1(1), 5-30.

Heller, D. E. (2002). The policy shift in state financial aid programs. In J. C. Smart (Ed.), Higher education: Handbook of theory and research (Vol. 17, pp. 221261). New York: Agathon Press.

Hovey, H. (2001). State funds for higher education: Fiscal decisions and policy implications. In J. L. Yeager, G. M. Nelson, E. A. Potter, J. C. Weidman, \& T. G. Zullo (Eds.), ASHE reader on finance in higher education (pp. 179-198). Boston: Pearson Custom Publishing.

Institute for Higher Education Policy. (2002). Accounting for state aid: How state policy and student aid connect. Washington, DC: Author.

Kane, T. J. (1995). Rising public college tuition and college entry: How well do public subsidies promote access to college? Cambridge, MA: National Bureau of Economic Research.

Kane, T. J. (1999). The price of admission: Rethinking how Americans pay for college. Washington, DC: Brookings Institution Press.

Kipp, S. M., Price, D. V., \& Wohlford, J. K. (2002). Unequal opportunity: Disparities in college access among the 50 states. Indianapolis, IN: Lumina Foundation for Education.

Maryland Department of Planning. (2002). Census 2000 data and information. Annapolis, MD: Author.

Maryland General Assembly. (2003). Operating Budget Analysis Documents: FY2004, Maryland Prepaid College Trust (R60H). Annapolis, MD: Author. Retrieved in April 2003 from www.mlis.state.md.us/\#budg.

MHEC. (1992). Maryland student financial support. Annapolis, MD: Maryland Higher Education Commission.

MHEC. (1994). Maryland student financial support. Annapolis, MD: Maryland Higher Education Commission.

MHEC. (1996). Maryland student financial support. Annapolis, MD: Maryland Higher Education Commission.

MHEC. (1998). Maryland student financial support. Annapolis, MD: Maryland Higher Education Commission.

MHEC. (2000). Maryland student financial support. Annapolis, MD: Maryland Higher Education Commission.

MHEC. (2001). Access and affordability: Refocusing financial aid in Maryland. Annapolis, MD: Maryland Higher Education Commission. (MHEC 2001-06)

MHEC. (2002a). Maryland student financial support. Annapolis, MD: Maryland Higher Education Commission.

MHEC. (2002b). Trends in financial aid to students in Maryland postsecondary education. Annapolis, MD: Maryland Higher Education Commission. (2002RES-3) 
MHEC. (2003). Trends in higher education: 2003. Annapolis, MD: Maryland Higher Education Commission.

MICUA. (2003). History of Maryland's Independent Higher Education Commission and MICUA. Annapolis, MD: Maryland Independent College and University Association. Available on www.micua.org.

MSDE. (2002a). Aid to education (R00A02). Baltimore, MD: Maryland State Department of Education.

MSDE. (2002b). How do we test what students have learned? Baltimore, MD: Maryland State Department of Education. Retrieved in April 2003 from www.mdk12.org/mspp/high_school/index.html.

MSDE. (2003). Maryland school performance report: State, systems, schools. Baltimore, MD: Maryland State Department of Education. Retrieved in April 2003 from www.msde.state.md.us.

Morgan, F. B. (2001). Fall enrollment in Title IV degree-granting postsecondary institutions: 1998. Washington, DC: U.S. Department of Education. (NCES 2002162)

Mumper, M. (2001). State efforts to keep public colleges affordable in the face of fiscal stress. In M. B. Paulsen \& J. C. Smart (Eds.), The finance of higher education: Theory, research, policy, and practice (pp. 321-354). New York: Agathon Press.

NCES. (2001). Condition of education, 2001. Washington, DC: U.S. Department of Education.

NCES. (2003a). Digest of education statistics, 2002. Washington, DC: U. S. Department of Education.

NCES. (2003b). Condition of education, 2003. Washington, DC: U.S. Department of Education.

National Center for Public Policy and Higher Education. (2002). Measuring up. Washington, DC: Author.

Paulsen, M. B. (2001a). The economics of the public sector: The nature and role of public policy in the finance of higher education. In M. B. Paulsen and J. C. Smart (Eds.), The finance of higher education: Theory, research, policy, and practice (pp. 95-132). New York: Agathon Press.

Paulsen, M. B. (2001b). The economics of human capital and investment in higher education. In M. B. Paulsen and J. C. Smart (Eds.), The finance of higher education: Theory, research, policy, and practice (pp. 55-94). New York: Agathon Press.

Paulsen, M. B. (2001c). Economic perspectives on rising college tuition: A theoretical and empirical exploration. In M. B. Paulsen and J. C. Smart (Eds.), The finance of higher education: Theory, research, policy, and practice (pp. 193263). New York: Agathon Press.

Perlstein, L. (2004, January 4). MD high school tests bring little progress. Washington Post, p. C6.

Perna, L. W. (in press). The key to college access: A college preparatory curriculum. In W. G. Tierney, Z. Corwin, \& J. Colyar (Eds.), Nine propositions relating to the effectiveness of early intervention programs. Albany: State University of New York Press. 
Perna, L. W., \& Titus, M. (2004). Understanding differences in the choice of college attended: The role of state public policies. Review of Higher Education, 27(4), 501-525.

Rawlings, H. P., \& Ards, S. (1997). Developing new strategies for enhancing access to college in Maryland. In State Higher Education Executive Officers and Education Commission of the States (Eds.), State strategies to address diversity and enhance equity in higher education (pp. 17-24). Denver, CO: Authors.

Roth, A. P. (2001). Saving for college and the tax code: A new spin on the "who pays for higher education?" debate. New York: Garland Publishing.

Shapiro, N. (2003). The Maryland partnership for teaching and learning: A state system perspective on K-16. Peer Review, 5(2), 24-26.

Sireci, S., Zanetti, M., \& Berger, J. (2003). Recent and anticipated changes in postsecondary admissions: A survey of New England colleges and universities. Review of Higher Education, 26, 323-342.

Southern Education Foundation. (1998). Miles to go: A report on Black students and postsecondary education in the South. Atlanta, GA: Author.

State Board of Education. (1996). Graduation requirements for public high schools in Maryland. Annapolis, MD: Author.

State Higher Education Executive Officers and Education Commission of the States. (1997). State strategies to address diversity and enhance equity in higher education. Denver, CO: Author.

Steuerle, C. E. (2001). A principled approach to educational policy. National Tax Journal, 54, 351-365.

Task Force to Study the Governance, Coordination, and Funding of the USM. (1999). Final report. Annapolis, MD: Author.

U.S. Department of Labor. (1990). Geographic profile of employment and unemployment, 1990. Washington, DC: Author.

U.S. Department of Labor. (1992). Geographic profile of employment and unemployment, 1992. Washington, DC: Author.

U.S. Department of Labor. (2000). Geographic profile of employment and unemployment, 2000. Washington, DC: Author.

USM Board of Regents. (2000). The USM in 2010: Responding to the challenges that lie ahead. Adelphi, MD: Author.

USM Office of Administration and Finance. (2003). General fund history. College Park, MD: Author.

Winston, G. C. (1999). Subsidies, hierarchies, and peers: The awkward economics of higher education. Journal of Economic Perspectives, 13(1), 13-36.

Young, B. A., \& Hoffman, L. (2002). Public high school dropouts and completers from the Common Core of Data: School years 1991-92 through 1997-98. Washington, DC: U.S. Department of Education, Office of Educational Research and Improvement (NCES 2002-317).

Zumeta, W. (1992). State public and private higher education. Journal of Higher Education, 63, 363-417. 